\title{
Madness and the Law: The Derrida/Foucault debate revisited
}

\section{Jacques de Ville}

\begin{abstract}
In this article the Derrida/Foucault debate is scrutinised with two closely related aims in mind: (1) reconsidering the way in which Foucault's texts, and especially the more recently published lectures, should be read; and (2) establishing the relation between law and madness. The article firstly calls for a reading of Foucault which exceeds metaphysics with the security it offers, by taking account of Derrida's reading of Foucault as well as of the heterogeneity of Foucault's texts. The article reflects in detail on a text of Derrida on Foucault ('Cogito and the History of Madness') as well as a text of Foucault on Blanchot ('Maurice Blanchot: The Thought from Outside'). The latter text shows that Foucault was at times acutely aware of the difficulty involved in exceeding metaphysics and that he realised the importance in this regard of a reflection on literature. These reflections tie in closely with Foucault's History of Madness as well as with Derrida's reflections on literature and on madness. Both Derrida and Foucault contend that law has much to learn from literature in understanding the relation between itself and madness. Literature more specifically points to law's 'origin' in madness. The article contends that a failure to take seriously this origin, also in the reading of Foucault's lectures, would amount to a denial by law of itself.
\end{abstract}

Keywords Madness - Derrida · Foucault - Descartes · Freud · Blanchot - Cogito · Language $\cdot$ Death $\cdot$ Reason

\section{Introduction}

Whether acknowledged or not, the question of madness has arguably always been of central concern for philosophical thinking. This is seemingly different from the position in law where madness generally seems to play a much more restricted role, in modern law more specifically because of the assumptions of 'normal' subjectivity. Michel Foucault and Jacques Derrida can be said to have questioned radically the predominant position as to the relationship between law and madness, showing that madness is as important for law as it is for philosophical thinking. Derrida's claims are perhaps the best-known in this regard. In 'Force of Law: The "Mystical Foundation of Authority"', he describes justice inter alia as 'without reason and without theoretical rationality, in the sense of regulating mastery'. He then notes that 'one can recognize in it, even accuse in it a madness', and adds that 'deconstruction is mad about and from such justice, mad about and from this desire for justice' (Derrida 2002, p. 254). With reference to Kierkegaard, Derrida (2002, p. 255) furthermore refers to the instant of decision as madness. This assessment of the relation between 
law and madness stems at least partly from Derrida's earlier debate with Foucault on the question of madness. ${ }^{1}$ In Derrida's 1963 lecture 'Cogito and the History of Madness' (Derrida 1978, pp. 31-63), which also includes a reference to the abovementioned passage from Kierkegaard, he provides a detailed reading of Foucault's History of Madness, published in 1961 (Foucault 2006). Foucault responded in 1972 in two texts which have recently been included in the first complete English translation of the History (Foucault 2006, pp. 550-590).2 Although the debate between Derrida and Foucault has been the subject of much academic discussion, 3 the relation between the Foucault/Derrida debate and law has not as yet been fully explored. This debate is of great importance for the current attempts to revisit Foucault's thinking on law in light of the recently published lectures. 4

The present article will enquire into the relation between law and madness in the texts of Derrida and Foucault, showing how this relation ties in closely with language and desire. This enquiry will concern itself with the 'site' from which Foucault launches his radical critique of the practices of modernity which we tend to view as 'normal' and arguably allows for Foucault's project to be further radicalised. Although Derrida's texts will be afforded a certain privilege, what is at stake here is not simply a 'Derridean' reading imposed upon Foucault but the exploration of the heterogeneity in Foucault's own texts. Apart from the History, a text of Foucault that will be looked at in some detail in exploring this heterogeneity is 'Maurice Blanchot: The Thought from Outside', published in 1966 (Foucault and Blanchot 1990, pp. 758). The importance of this text lies in the exploration there by Foucault of the law of literature which ties in closely with Derrida's reading of the History of Madness, with Derrida's explorations of literature, as well as with Derrida's thinking on law and justice. The article will start with a reading of 'Cogito and the History of Madness', which will take place also with reference to 'To do Justice to Freud' where Derrida (1998, pp. 70-118) explains the background to his 'Cogito' essay. 5 This will assist us in our discussion of Foucault's 'Maurice Blanchot: The thought from Outside' which will follow thereafter. The article will conclude by pointing to the implications of these readings of Foucault and Derrida for law. These texts on madness, desire, death and language, it will be contended, allow the law itself to appear in its inevitable withdrawal.

\section{Cogito and the History of Madness}

In his reading of Foucault's History of Madness, Derrida focuses primarily on the Preface of the History as well as Foucault's reading of Descartes's Meditations (1641)

\footnotetext{
${ }^{1}$ For other reflections of Derrida on madness, see also Derrida and Thévenin (1998) and Derrida (2008, pp. 87103).

${ }^{2}$ An abridged edition was published in English in 1967 as Madness and Civilization; A History of Insanity in the Age of Reason, based for the most part on an abridged French edition published in 1964.

${ }^{3}$ Excellent commentaries on this debate are provided by inter alia Felman (1975); Flynn (1989); McNay (1994, pp. 31-37); and Naas (2003, pp. 57-75).

${ }^{4}$ See Golder and Fitzpatrick (2009) who ably summarise the issues at stake in this regard.

5 The debate with Foucault was in a sense continued posthumously in this essay, which traces the intersection between the thinking of Foucault and Freud. For reasons of space this essay cannot be analysed here in detail.
} 
in chapter II of part one of the History. Only a small part of Foucault's History of Madness concerns itself explicitly with an interpretation of Descartes's Meditations, but according to Derrida the whole of Foucault's project is tied to this interpretation. ${ }^{6}$ Despite appearances to the contrary, Derrida does not seek to undermine Foucault's project or place it in question, but rather to sharpen its edges 'philosophically'.7 In analysing these two texts, and before engaging in a fairly detailed analysis of Derrida's reading of Descartes's Meditations, we will seek answers to the following questions:

- Can a history of madness be written?

- From which 'site' does Foucault write his history of madness?

- When did the 'internment' of madness start?

- With which concept of madness does Foucault work?

The impossibility of a history of madness

Central to Derrida's concerns is Foucault's claim to write the archaeology of the silence imposed on madness through the division between madness and reason. In other words, Foucault attempts to write a history of madness itself, by letting madness itself speak (Derrida 1978, pp. 33-34; Foucault 2006, pp. xxviii, xxxii). Stated differently, Foucault does not want to write this history from within the language of reason, of madness interned, but of madness before its capture by knowledge. This history, as Derrida (1978, p. 34) puts it, purports to be a history of untamed madness before being caught by classical reason, whilst using the language that was used to capture madness. The language of reason is however itself the language of order and of the system of objectivity which necessarily captures or objectifies madness. This raises the question whether a 'history' of silence can in fact be written, as all history, per definition, is of rationality and meaning in general (Derrida 1978, p. 308 n. 4). In his later discussion of Descartes's Meditations, Derrida (1978, pp. 53-54) phrases this principle thus:

[I]f discourse and philosophical communication (that is, language itself) are to have an intelligible meaning, that is to say, if they are to conform to their essence and vocation as discourse, they must simultaneously in fact and in principle escape madness....By its essence the sentence is normal.

The question this raises is whether one can, by elaborating on the ways in which psychiatry has excluded reason and by suspending the language of psychiatry, return to innocence and end one's own complicity in the exclusion of madness by the rational and political order (Derrida 1978, p. 35; Flynn 1989, p. 203). The psychiatrist is after all only a delegate of this order, one of many. As Derrida points out, all

\footnotetext{
${ }^{6}$ This is borne out, at least superficially, by Descartes's re-appearance in various places throughout the History of Madness.

${ }^{7}$ The quotation marks are required here because of Derrida's relation to philosophy. As is well-known, he is not simply opposed to philosophy (a position which Foucault at times adopts and which as we will see below ultimately remains philosophical), but seeks to exceed philosophy from within in a rigorous manner.
} 
European languages are implicit in the adventure of Western reason as well as in the delegations which have led to the capture of reason. It therefore seems to be impossible to put on trial this history (of the objectification of madness) as Foucault seeks to do, as the proceedings as well as the verdict are, due simply to their articulation, bound to repeat the crime. Even an archaeology of silence amounts to a logic, an organised language, an order and a work. Foucault's archaeology of silence therefore effectively amounts to a repetition of the act of excluding and objectifying madness, also at the moment when this exclusion is denounced (Derrida 1978, pp, 35, 53-54). Derrida (1978, pp. 36-37) nevertheless reads Foucault as being aware of this, at least on a certain level, as Foucault at certain points acknowledges the impossibility of writing this archaeology of silence. Foucault (2006, p. xxxii) for example acknowledges the necessity and impossibility of having to write this history without the support of the syntax of reason. Derrida comments that Foucault could perhaps be said to perform this feat (that is, his archaeology of silence) through his practice rather than his formulation. In other words, because the silence cannot be spoken without at the same time re-captivating it within logos - the language of objectification - Foucault gives expression to it through his pathos, by means of his new and radical silent praise of folly. Behind Foucault's explicit project, another project can thus be said to take place in silence. ${ }^{8}$ This raises the question of conditions of possibility. What makes possible Foucault's feat? How does it happen that Foucault can at the point in time that he writes his History of Madness, understand and enunciate this breaking point in the classical age (spanning approximately from 1650 to 1800 ) between a determined reason and a determined madness (to be distinguished from reason and madness in general)? Foucault does not explicitly reflect on this in his History. Derrida's contention is that this could happen only because of a certain liberation of madness, because a dislocation between madness and unreason had already gotten underway in psychiatry (Derrida 1978, p. 38). Implicit in this statement is the importance of Freud's thinking, which as Derrida suggests, made possible Foucault's project (Derrida 1998, p. 73). ${ }^{9}$

Behind Foucault's projected archaeology of silence, another project is therefore engaged in. To understand what is at stake here, we need to enquire into the way in which these two projects proceed. Because the silence of madness is not an original silence but one which (according to Foucault) was imposed at a certain point in history, Foucault feels the need to find the origin of this imposition. He has to find the origin of the separation between reason and madness (unreason) in contrast with their free circulation and exchange up to that point (Derrida 1978, p. 38). Foucault (2006, p. xxxiii) refers to this origin as 'the decision'. According to Derrida (1978, pp. 38-39) a slight change in vocabulary is required here: the split between reason and madness should rather be referred to as a 'dissension', in order to point to the self-

\footnotetext{
${ }^{8}$ These comments clearly show that a reading of Derrida's 'Cogito' which is to the effect that he believes that there is no escape from or no space outside of reason (see Boyne 1990, pp. 53-89) is on the wrong track.

9 Derrida's enquiry into the (ambivalent) relation between Foucault and Freud in 'To do Justice to Freud' (Derrida 1998, pp. 70-118), focuses specifically on the relation between Freud's reflections on the death drive in Beyond the Pleasure Principle (Freud 2001, pp. 1-64) and the 'space' within which Foucault's project is inscribed. Derrida's reading of Freud's death drive ties in closely with the discussion of literature below (Derrida 1987a, pp. 257-409).
} 
dividing action at stake here, that is, what is made exterior, is the interior (Derrida 1978, pp. 38-39). Once one recognises the importance of this change in vocabulary, a number of questions are raised which require a rethinking of some aspects of Foucault's analysis. These relate specifically to the question referred to earlier as to when the internment of madness started. Foucault (2006, p. xxix) more particularly presents the Greek logos as having had no contrary. At the same time he refers to the 'reassuring dialectic of Socrates' in relation to the Greek notion of hybris, which as Derrida (1978, p. 40) points out, shows (when read together with the texts of Greek philosophers) that the Greek logos had 'already expulsed, excluded, objectified or (curiously amounting to the same thing) assimilated and mastered as one of its moments, "enveloped" the contrary of reason'. This means, contrary to Foucault's assertion, that the separation between reason and its other had not taken place (for the first time) in the classical age, but long before then. The entire history of philosophy and of reason bears witness to this struggle. Since the Greeks, reason has been divided against itself, and whatever happened afterwards (including the events as described by Foucault) are only socio-economic epiphenomena that take place on the surface. Madness therefore does not start being confined in the classical age; this internment already starts with the awakening of language. The risk Foucault runs in writing a history of madness in this way is to assume a unity of original presence followed by a subsequent event of division, thereby confirming metaphysics in its fundamental operation. ${ }^{10}$

This brings us to the question of the concept of madness in the History. Derrida (1978, p. 41) points out that the concept of madness is never submitted to thematic scrutiny by Foucault. Nonetheless,

everything transpires as if Foucault knew what "madness" means. Everything transpires as if, in a continuous and underlying way, an assured and rigorous precomprehension of the concept of madness, or at least its nominal definition, were possible and acquired. In fact, however, it could be demonstrated that as Foucault intends it, if not by the historical current he is studying, the concept of madness overlaps everything that can be put under the rubric of negativity.

The allusion here is of course to Hegel, and the implication is that Foucault understands madness in a restricted sense, more specifically in terms of the popular and equivocal notion of madness (Derrida 1978, p. 41). Derrida's 'understanding' of madness as we will see below is much more 'radical' for the reason, as he points out, that reason's constitution of itself, lies at the origin of history; it is historicity itself (Derrida 1978, p. 42). In other words, the exclusion of a certain madness is the condition of possibility of meaning and of language. This at the same time implies that what happens in the classical age as described by Foucault 'has neither absolute privilege nor archetypal exemplarity' (Derrida 1978, p. 42). It is merely an example

\footnotetext{
${ }^{10}$ As Flynn (1989, pp. 214-215) points out, the procedure of positing an inside and an outside (as Foucault does regarding reason and madness) is also a fundamental metaphysical move.
} 
among others of the way in which a certain madness is dealt with in history. As we will see below, much of this 'criticism' is later implicitly accepted by Foucault.

\section{Descartes's Meditations}

We next arrive at the important discussion of Descartes' Meditations, which Foucault engages in at the beginning of chapter II of part one of the History of Madness. It goes to the heart of the question of the 'meaning' of madness and thus requires careful scrutiny. Foucault views these passages as the philosophical internment of madness (Derrida 1978, p. 44) and we can see clearly from his reading how he understands madness in a restricted sense (in line with Hegel's negativity).11 Descartes in the First Meditation seeks to question all the opinions he has held up until then so as to ultimately arrive at a point where he holds onto only those opinions which are certain and indubitable. For this purpose he does not enquire into every opinion so held but only into its foundations. This is carried through in three successive stages. (1) He firstly enquires into the senses as a source of knowledge and points out that although our senses sometimes deceive us in relation to things that are not clearly perceptible and things at a great distance, it would be unreasonable to doubt certain things that are presented to our senses. The senses are in other words mostly trustworthy. For example, the fact that he is sitting by the fire, in his dressing gown, with a piece of paper in his hand of which he is aware through his senses, cannot reasonably be doubted. That is, unless he were a madman, who believes that he is a king when he is in fact poor; or who believes that he is wearing gold and purple when in fact he is naked; or who imagines that his head is made of earthenware, that he is a pumpkin or is made of glass. But, says Descartes, he himself is clearly not mad, and it would be foolish of him to follow their example and deny the truthfulness of the senses. (2) Let us then go further, says Descartes, and consider that I might be asleep and dreaming everything that my senses represent to me, that is, that I am sitting here in front of the fire, etc. In sleep we are after all often deceived into believing that what we experience is an experience in real life. Let us assume then that I am asleep, Descartes says, are there then not still certain things which remain indubitable? Indeed. It is like a painter who paints something which does not exist in reality. Even then the forms or at least the colours will be real. Similarly physics, astronomy, medicine etc., may contain many doubtful things, but ultimately they are based on mathematics, geometry and other similar sciences which, despite the fact that they may not exist, are certain and indubitable. These are in other words truths of a nonsensory origin which are true, whether or not one is awake or asleep (Derrida 1978, p. 46). Even if I am asleep, Descartes concludes, 'two and three together always make five, and a square never has more than four sides' (Descartes 1968, p. 98). (3)

\footnotetext{
${ }^{11}$ See in this respect the confession of Foucault in Foucault Politics, Philosophy, Culture 312: '[W]hat remained of traditional philosophical discourse in the work that I had done on the subject of madness embarrassed me. There is a certain Hegelianism surviving there. It isn't necessarily enough to deal with such menial things as police reports, measures taken for confinement, the cries of madmen to escape from philosophy. For me Nietzsche, Bataille, Blanchot, Klossowski were ways of escaping from philosophy.' How especially Blanchot assists in this respect, we will see below.
} 
Descartes then goes even further to place all his certainties in doubt, this time by going beyond both sensory and non-sensory foundations, and questions the metaphysical foundations of his knowledge. He now imagines that the God in whom he has always believed as being all-powerful may actually be an evil genius who has decided to deceive him so that all the certainties he has just established are only such because of deception. This places in doubt all his certainties, Descartes acknowledges.

For Foucault, the most important passage in the above process of questioning lies in the first section, and specifically in the following sentence of Descartes (1968, p. 96): 'But these are madmen, and I would not be less extravagant if I were to follow their example'. Foucault focuses his analysis on the first two parts of the procedure ((1) and (2) above) and draws a distinction between three forms of doubt: (a) error of the senses, (b) dreams and (c) madness. In the case of (a) and (b), truth does not slip away completely. There is still a residue of truth that remains in both instances. In the words of Foucault (2006, p. 45):

Thus neither sleep peopled with images nor the clear consciousness that the senses are deceived can lead doubt to its most universal point: we might admit that our eyes can deceive us, and "suppose we are asleep", but the truth will never slip away entirely into darkness.

It is however different with madness. Here all truth dissolves, Foucault contends. Descartes consequently does not delve on it as extensively as he does on dreams, but simply excludes it by decree as appears from the quotation from Descartes's Meditations referred to above. This is because to think (ego cogito ergo sum) excludes the possibility of being mad. There can be little doubt about the originality of this reading which provides an excellent introduction to this chapter which will, following upon this 'philosophical internment', continue to trace the political decree of the great internment of madness. It however comes at a price. Apart from the fact that Descartes's text needs to be distorted to arrive at this reading, ${ }^{12}$ it restricts the meaning of madness to something calculable and excludes from the reading Descartes's consideration of 'total madness' which exceeds metaphysics. This 'total madness' nonetheless corresponds with Foucault's definition of madness as 'the absence of a work' or 'the absence of an œuvre' (Derrida 1978, p. 54; Foucault 2006, p. xxxi). 13

In his analysis of Descartes's First Meditation, Derrida (1978, p. 48) points out that Descartes does not, as Foucault contends, 'sidestep the possibility of dream or error' and that it is not the case that '[d]reams and illusions are overcome by the very structure of truth' (Foucault 2006, pp. 44 and 45). There is firstly no sidestepping or circumvention because Descartes follows a procedure in which firstly the senses are

\footnotetext{
${ }^{12}$ Derrida's contentions in this regard clearly show that he is not of the view that correctness in reading is no longer a requirement. Correctness and truth are displaced in Derrida's thinking, not discarded. This said, Derrida's reading of Descartes is by no means an orthodox one.

${ }_{13}$ Alan Bass, the translator of Derrida's 'Cogito' understands this as a work which is not governed by institutionalised rationalism; Derrida (1978, p. 308 n. 6). We will return to this again in Foucault's description of Blanchot's 'novels'.
} 
questioned and then radically or hyperbolically placed in doubt (steps (1) and (2) above), whereafter even mathematical truth (which is all that remains after raising these 'natural' reasons for doubt) does not escape from being placed in doubt. Mathematical truth will more specifically be placed in doubt by 'the artificial and metaphysical assault of the evil genius' (Derrida 1978, p. 46). According to Derrida, the reason why Descartes deals with dreams in greater detail (than with the other forms of sensory deception) is because what applies in the case of dreams, applies with even stronger reason in the case of sensory perception: certainties and truths of a non-sensory and non-imaginative ${ }^{14}$ origin are the only ones that escape sensory error and oneiric composition (Derrida 1978, p. 48). Sensory and imaginative sources can thus not provide one with certainty. Dreams and illusions consequently also cannot, as Foucault contends, be overcome or surmounted by the structure of truth, because Descartes is prepared to posit the possibility of total error for all knowledge gained from the senses and imaginary constructions. The only certain things which remain at this point (before the arrival of the evil genius) are that which is simple (such as colour) and intelligible (Derrida 1978, p. 49). Insofar as the purely intelligible (for example, two plus three equals five) still remains at this point (a provisional certainty which is no longer of a sensory or imaginative nature) it will, as said before, be placed radically in doubt in the next step. The 'exclusion' of madness at this point moreover does not occur for the reasons Foucault asserts, but simply because the madness that is invoked here (the popular and everyday idea of madness) is not wrong about everything, is not mad enough. Madness in this form does not provide the most serious form of sensory illusion. In this sense, the dreamer is more insane than the madman (Derrida 1978, p. 50) and the invocation of the evil genius will proceed further to posit the possibility of total madness.

Wherein lies the importance of Descartes's evil genius and the importance of taking account of it in writing a history of madness? We are of course at this point no longer concerned with natural doubt (stages (1) and (2)) but the fiction or hypothesis of the evil genius (stage 3). Derrida's description of the total madness that is at stake here clearly goes beyond the popular conception thereof and is of great importance for the rest of our discussion:

Now, the recourse to the fiction of the evil genius will evoke, conjure up, the possibility of a total madness, a total derangement over which I could have no control because it is inflicted upon me - hypothetically - leaving me no responsibility for it. Total derangement is the possibility of a madness that is no longer a disorder of the body, of the object, the body-object outside the boundaries of the res cogitans, outside the boundaries of the policed city, secure in its existence as thinking subjectivity, but is a madness that will bring subversion to pure thought and to its purely intelligible objects, to the field of its clear and distinct ideas, to the realm of the mathematical truths which escape natural doubt (Derrida 1978, pp. 52-53).

\footnotetext{
${ }^{14}$ As examples of products of the imagination, Descartes (1968, p. 97) refers to pictures and painting.
} 
Derrida at this point seeks to, at least partially, defend Descartes from Foucault's accusation to the effect that he (Descartes) was the first philosopher to intern madness through an act of force and exteriorise it from the Cogito (I who think, I cannot be mad), upon which followed the political internment. Derrida's contention here, tying in with our discussion above, is firstly that the 'exclusion' of madness is not something that happens at a determinate point in history. If madness is indeed the absence of a work, as Foucault contends, then language by its nature excludes madness which is essentially silence, stifled speech (Derrida 1978, p. 54).15 This is not imposed at one determinate moment in history rather than another (for example with Descartes) but is linked to an act of force which opens up history and speech in general. This silence, like non-meaning, furthermore continues to haunt language as its resource. At stake here is not a determinate language, for example Latin or French (the languages of Descartes), but language in general. Through his own language (in general), Descartes reassures himself that he is not insane. Language, conceived in its essence (in other words, metaphysically) therefore entails the break with madness, and it adheres more thoroughly to its essence and vocation, makes a cleaner break with madness, if it pits itself against madness more freely and gets closer and closer to it' (Derrida 1978, p. 55). Foucault's History, Derrida contends, similar to Descartes's Meditations, seeks to in this way get closer to madness so as to protect itself against it and to intern it.

Madness is moreover not simply exterior to philosophy as Foucault contends, especially after Descartes. The certainty of the Cogito is attained not by containing or interning madness, but by asserting itself in the midst of madness. Descartes's argument in other words amounts to the following: 'I think, even if I am completely mad'. Derrida (1978, p. 56) reads Descartes here as going beyond a determined reason and a determined unreason to a 'zero point at which determined meaning and nonmeaning come together in their common origin'. ${ }^{16}$ This is the 'moment', as Derrida (1978, p. 58) adds later, 'when reason and madness have not as yet been separated'. Derrida finds in this 'point' the condition of possibility of Foucault's narration of the history of madness. ${ }^{17}$ It is from this point that determinate forms of the opposition between reason and unreason can appear as such and be stated. At this point, which is also the proper and inaugural moment of the Cogito, there is as Derrida (1978, p. 56) notes, still very little certainty attached to the Cogito - it is not in the least reassuring. ${ }^{18}$ Descartes's project is in this respect not dissimilar to that of Socrates who contemplates the good beyond being (epekeina tes ousias) which Glaucon in Plato's Republic refers to as a 'daemonic superiority' (Plato 1997, pp. 11291130 [509b-c]). The latter is as little reassuring and far exceeds the Greek notion of hybris, if we understand the latter as a pathological modification in man (Derrida

\footnotetext{
${ }^{15}$ These passages should not be understood as an indication of essentialism on Derrida's part. What he describes here is the essence of language in metaphysics.

${ }^{16}$ The notion of 'origin' should be placed in quotation marks, because what is at stake here is more precisely a pre-origin, the 'origin of origin'.

${ }^{17}$ Derrida (1978, p. 309 n. 24) also notes that it is less a question of 'point' than of an original temporality, or what he elsewhere refers to as a 'past that has never been present'; see Derrida (1986, p. 79b).

${ }^{18}$ There is of course an allusion here to Foucault (2006, p. xxix), who as we saw earlier, refers to 'the reassuring dialectics of Socrates'.
} 
1978, p. 57). Foucault, by ignoring or not giving sufficient attention to Descartes's radical placing in question of all certainties through his invocation of the evil genius, excludes total madness from consideration and thus performs an even greater exclusionary act than he (unfairly) accuses Descartes of performing. ${ }^{19}$ Foucault in other words reduces Descartes's project and encloses it within a determined historical structure, whereas what is at stake here far exceeds this structure. Derrida (1978, p. 309 n. 26) therefore provocatively refers to Foucault's discourse as being totalitarian in as far as it 'risks erasing the excess by which every philosophy (of meaning) is related, in some region of its discourse, to the nonfoundation of unmeaning'. The 'totalitarian' nature of Foucault's discourse also appears from his reading of Descartes to the extent that it involves a certain violence which reduces that which is hyperbolic (in Descartes) to what is intra-worldly. It is this violence which makes possible our conception of madness or what Derrida (1978, p. 57) refers to as the 'making possible [of] all straitjackets'.

After having reached this extreme point, Descartes however immediately seeks to reassure himself by certifying the Cogito through God and by identifying the act of the Cogito with a reasonable reason (Derrida 1978, p. 58; Derrida 1974, pp. 97-98; Derrida 1982, pp. 294-296). He does this when he needs to temporalise the Cogito. Descartes contended earlier that the Cogito is valid only at the point where thought is attentive to itself (Derrida 1978, p. 58) which means that it needs to reassure itself through the positing of that which is stable and infinite (God and reason). In the end, as Derrida (1978, p. 58) notes, it is God alone (that is reason) who protects Descartes from the madness which the Cogito, left to itself, opens itself up to in the most hospitable way. ${ }^{20}$ Tying in with what was said earlier about the relation between language and reason, when one (as Descartes does), contemplates and retains the Cogito, communicates it as well as its meaning, one must not be mad. Viewed from the other side, to be mad is to not be able to make the Cogito as such appear to any other - even to myself. The madman, even if he could repel the evil genius, would not be able to tell himself this. He thus cannot say it, cannot express it in reasonable language (Derrida 1978, p. 59). This is, as we saw above, because language in its essence is reason and logos and constitutes the break with madness (Derrida 1978, p. 55). From Descartes's Meditations it therefore appears that philosophy is 'the reassurance given against the anguish of being mad at the point of the greatest proximity to madness' (Derrida 1978, p. 59).

What happens in Derrida's reading of Descartes is that the Cogito is divided into hyperbole which cannot be contained within a determined historical structure on the one hand, and a finite structure - that which can be so contained, on the other. It is this division which according to Derrida (1978, p. 60) defines the history of philosophy and makes historicity possible. Philosophy can in other words only exist by constantly imprisoning and oppressing madness, the madman within us (Derrida 1978, p. 61). Foucault (2006, p. 343) notes something similar, stating that a power of

\footnotetext{
${ }^{19}$ This hyperbolic project, different from the rest of Descartes's project, is in other words not something which can be reduced to a determined historical structure; Derrida (1978, p. 57).

${ }^{20}$ This seemingly chance reference to hospitality will be taken up in Derrida's texts of the 1990s and thereafter; see eg Derrida and Dufourmantelle (2000); Derrida (1999), and see further below.
} 
unreason constantly keeps vigil around the Cogito. There is moreover, Derrida (1978, p. 60) adds, a continuing or unending dialogue in history between that which exceeds totality and that which is enclosed within totality. This constant movement is referred to by Derrida as différance, and he describes its functioning in Descartes's Meditations as follows:

[T]o-attempt-to-say-the-demonic-hyperbole from whose heights thought is announced to itself, frightens itself, and reassures itself against being annihilated or wrecked in madness or in death. At its height hyperbole, the absolute opening, the uneconomic expenditure, is always reembraced by an economy and is overcome by economy. The relationship between reason, madness, and death is an economy, a structure of deferral whose irreducible originality must be respected (Derrida 1978, pp. 61-62).

Derrida's contention in 'Cogito' could be summarized by saying that Foucault's archaeology of the silence of madness which exposes the distinction between reason and its other (madness) which is excluded finds itself positioned within a broader framework which operates on the basis of a more radical exclusion (of total madness). What Foucault describes is therefore a symptom of a broader phenomenon which characterises language and reason. Derrida can consequently be said to in large part agree with Foucault, whilst at the same time contending that what Foucault writes about in a determined age, applies to reason and language in general. In a sympathetic reading, Foucault can be shown to be aware of this, and to be engaging in such an analysis too. It is important to note that Derrida does not in any way cast doubt on the importance, necessity and legitimacy of Foucault's project. ${ }^{21}$ He simply repeats what Foucault says about the concept of madness with reference to a madness which breaches all limits.

Foucault and others however understood Derrida's reading as an attack in relation to his whole project or at least as the expression of an opposition to (all of) Foucault's thinking. ${ }^{22}$ In his first response, published in the Japanese journal Paideia in February 1972 (now also included as an appendix in the History), Foucault (2006, p. 578) seeks to (further) distance himself from philosophy and furthermore to situate philosophy within the sphere of knowledge. Philosophy, Foucault asserts, does not provide a foundation for knowledge. Philosophical discourse in a given period is instead subject to conditions and rules for the formation of knowledge in the same way as any other form of discourse with rational pretension. The question which Foucault's stance raises is whether philosophy can indeed be escaped by historicising it and then simply stepping outside of it. Both questions must be answered in the negative. In the first place, reason or meaning in general, which as we saw can be equated with the idea and name of God, cannot be historicised in this way without deceiving oneself (Derrida 1978, pp. 309-310 n. 27 and 28). This is because there is a

\footnotetext{
${ }^{21}$ See also Derrida (1998, p. 113) and Derrida and Roudinesco (2004, pp. 6, 10-12)

${ }^{22}$ Foucault (2006, pp. 550-590).
} 
'oneness' to reason which leaves one with limited options in protesting against it (Derrida 1978, p. 36). Secondly, all our concepts and the way in which they are organised, in this case, the concepts of madness, of experience, and of the event as well as the inside/outside distinction which Foucault (2006, p. 589) again invokes, stem from the Greek dawn of western philosophy and are consequently metaphysical in nature (Derrida 1978, p. 40). As we saw above, one of Derrida's main arguments in 'Cogito' and elsewhere is precisely that in believing that a simple escape from metaphysics is possible, one somewhat naively ends up repeating the gestures of metaphysics. The concept of history (archaeology) which Foucault employs here is, as we saw earlier, itself rational in nature (Derrida 1978, p. 36). The Hegelian dialectic, which is clearly at stake here, cannot in other words be successfully challenged from a position which believes itself to be simply exterior to philosophy. It can only be challenged from within (Derrida 1978, p. 36). Insofar as the reading of Descartes is concerned, Foucault in both responses defends his earlier reading in relation to determined madness by relying on similar 'structural' arguments. Foucault (2006, pp. 570-572) furthermore rejects Derrida's argument, specifically in relation to the evil genius, for structural reasons. He contends that when Descartes speaks of the evil genius this is 'a voluntary exercise, controlled, mastered and carried out from beginning to end by a meditating subject who never allows himself to be surprised' (Foucault 2006, p. 571). Derrida is said to erase this from Descartes' text. This indeed appears to be the case from Descartes's text, and Foucault cannot be accused of an incorrect reading. The difficulty with this reading is nevertheless its (metaphysical) assumption that Descartes, or for that matter any author, is capable of such an exercise. ${ }^{23}$ The reason why Derrida finds specifically this part of Descartes's Meditation attractive is because there madness as a concept is put into play. It shows the relation between thinking and madness, not only in the text of Descartes, but in that of all writers, because of the nature of writing. ${ }^{24}$ For Foucault this is not important, because of the nature of his project - attempting to show how reason interns its other at a specific point in history. As we saw above, this is done at a cost. Foucault's reading, also in his response to Derrida, has the consequence of excluding the (absolute) madness in ourselves from consideration. ${ }^{25}$

\section{Blanchot, Language and the law}

\footnotetext{
${ }^{23}$ The same would apply to Foucault, which is why the attempt to separate the (earlier) aesthetic and the (later) more political Foucault (see eg Rajchman 1983, pp. 37-62; and Freundlieb 1995, pp. 301-344), cannot be fully subscribed to; see also Golder and Fitzpatrick (2009, p. 94) and Santini and Lapidus (2002, p. 81) who argue in favour of a more integrated reading of Foucault in this respect, based on a continuity in his thinking. The contention of the present article, as will appear from the section that follows, is that Foucault's (earlier) relation to literature is something which was ultimately not possible to abandon. In other words, even if commentators are correct in asserting that Foucault explicitly rejected his earlier thinking on literature (which is by no means certain) this would not prevent any of his texts from being read in the manner proposed here; see also Saghafi (1996). An author is simply not able to constrain a text through his intention to prevent such a reading; see Derrida (1978, p. 178).

24 See also Flynn (1989, pp. 216-218). The accusation of textual solipsism on Derrida's part (Foucault 2006, p. 573; and Said 1978) is based on a grave misunderstanding; for a response to this accusation (by others), see Derrida (1988, p. 148).

${ }^{25}$ This is what Derrida implicitly points out in 'To do Justice to Freud' (1998, pp. 70-118), without directly responding to Foucault.
} 
We now arrive at the point where we need to consider more closely the relation of Foucault and Derrida to the law and to determine how this ties in with the discussion above of madness, language, death and desire. A text which ties in very closely with Derrida's reading of Foucault, is Foucault's 'Maurice Blanchot: The Thought from Outside', stemming from 1966 and published in book-form together with an essay of Blanchot on Foucault (Foucault and Blanchot, 1990). ${ }^{26}$ Foucault in this text, tying in with the confession referred to earlier of his having remained too Hegelian in the History of Madness, ${ }^{27}$ and in a clear attempt to exceed Hegel from within, analyses Blanchot's 'novels', 'narratives' and 'criticism' in general and in particular, The Most High (Le Très-Haut, 1948) and Aminadab (1942). No 'debate' between Derrida and Foucault took place specifically in relation to these 'novels', but Derrida through the years engaged with a number of texts of Blanchot in a way which ties in very closely with Foucault's reading. The above 'novels' of Blanchot can be said to involve a search for the 'pre-origin' or 'law' of language, and consequently also, because of their being bound to language, of literature and of law. Blanchot's statement in The Song of the Sirens gives vivid expression to what is at stake here (Blanchot 1999, p. 445): 'A very obscure struggle takes place between every tale and the encounter with the Sirens... What we call the novel was born of this struggle.' As we can see from this statement and as will appear from the discussion that follows, the law of language as described by Foucault is interwoven with death as well as with desire or what he refers to as 'attraction' and 'negligence'. The discussion will proceed in two steps. Firstly there will be an analysis of the close relation between language and death in these and other texts of Blanchot, which ties in closely with the relation between madness and language posited earlier. Secondly, we will enquire into Foucault's discussion of 'the law itself' in this text, and attempt to establish how this in turn ties in with Derrida's reflections on justice referred to in the introduction. It will appear from the analysis that the notion of 'law' as used here should not too quickly be equated with positive law or some aspect or characteristic of positive law.

\section{Language and death}

Foucault starts and ends his essay on Blanchot with an analysis of the phrase 'I speak', alluding therewith to the last sentence in The Most High which ends with the following words: 'Now, now I'm speaking'. ${ }^{28}$ This is the point at which Jeanne Galgut, the nurse of the main character, Henri Sorge, shoots him. Foucault contends that the 'I speak' of Blanchot puts the whole of modern fiction to the test. To understand something of what is at stake here, an enquiry into language and its relation to death is required. Foucault notes in this regard, with reference to Blanchot, that 'the word is

\footnotetext{
${ }^{26}$ In Golder and Fitzpatrick (2009, pp. 76-78) the importance of this text is emphasized in the context of Foucault's thinking on law, although not analysed in detail. See further Johnston (1990, pp. 802-804) on the relation between Foucault's reflections on madness and literature.

${ }^{27}$ See $n .11$ above.

${ }^{28}$ This passage is later in the text quoted by Foucault (Foucault and Blanchot 1990, pp. 39, 55) and identified with the law (of speaking).
} 
the manifest non-existence of what it designates' (Foucault and Blanchot 1990, p. 54; also at p. 18). Blanchot gives expression to this conception of language in 'Literature and the Right to Death' (Blanchot 1999, pp. 378-379). He points out there that language gives us power over that which is created through words, allowing us complete powers of manipulation, this however necessarily going along with the annihilation of 'reality'. Blanchot (1999, p. 379) in this respect follows Hegel. In a text dating from 1803-4 Hegel notes that in becoming master of animals, in giving them names, Adam had to annihilate them in their existence. The meaning and expression of speech thus depends on an annihilation of living things. Only then, by creating them from out of the death into which they had appeared, can they take on meaning. Man is in this way condemned to not be able to approach or experience anything but through the creation of meaning, that is, being (Blanchot 1999, pp. 379-380). Although my language does not kill anyone, it can be said to announce such death. Language in other words announces the possibility of the person here 'present' being removed from her existence and plunged into nothingness (Blanchot 1999, p. 380). This is moreover only possible because of the person I am referring to being capable of death, being threatened by death at every moment, bound and joined to death. ${ }^{29}$ Language can therefore be said to amount to a deferred assassination. When I speak, death consequently also speaks in me. When I speak, death appears between me and the person I speak to. It constitutes the distance between us, but it also makes understanding between us possible. It is in other words death which allows me to grasp what I want to attain. Death 'exists in words as the only way they can have meaning' (Blanchot 1999, p. 380). Without death, Blanchot (1999, p. 380) adds, 'everything would sink into absurdity and nothingness'.

Language is therefore negation, but this negation is made possible in the first place by the doubling of negation; in other words by 'a being capable of non-being' (Hartman 1955, 71), or perhaps rather, in light of what was said earlier, a being desiring its own non-being. . $^{\circ}$ Foucault therefore points out that we have also learnt (from inter alia Blanchot) that 'the being of language is the visible effacement of the one who speaks' (Foucault and Blanchot 1990, p. 54). Words thus imply not only the death of what is named, but also the death of the one who speaks. ${ }^{31}$ By saying my own name, I am singing my own mourning song (Blanchot 1999, p. 380). In the words of Blanchot (1999, pp. 380-381), thereby also explaining the 'unreadability' of The Most High and of Aminadab, which take seriously this law of language:

When I speak, I deny the existence of what I am saying, but I also deny the existence of the person who is saying it: if my speech reveals being in its nonexistence, it also affirms that this revelation is made on the basis of the nonexistence of the person making it, out of his power to remove himself from himself, to be other than his being. This is why, if true language is to begin, the life that will carry this language must have experienced its nothingness, must have "trembled in

\footnotetext{
${ }^{29}$ The same of course applies to other living beings as well as inorganic things, insofar as their death/destruction is concerned.

${ }^{30}$ See n. 9 above

${ }^{31}$ See similarly, 'Signature, Event, Context' in Derrida (1982, pp. 307-330).
} 
the depths; and everything in it that was fixed and stable must have been shaken." Language can only begin with the void; no fullness, no certainty can ever speak; something essential is lacking in anyone who expresses himself. Negation is tied to language. When I first begin, I do not speak in order to say something, rather a nothing demands to speak, nothing speaks, nothing finds its being in speech and the being of speech is nothing. This formulation explains why literature's ideal has been the following: to say nothing, to speak in order to say nothing.

Foucault clearly subscribes to the above, as can be seen in his analysis of the 'I speak' with which as noted earlier The Most High ends, or more precisely, commences, because this 'novel' is the outcome of Henri Sorge's death, literature gaining 'from death the possibility of speaking and the truth of speech' (Blanchot 1999, p. 378).32 Blanchot's 'I speak' thus raises the question of language in its 'raw state', 'an unfolding of pure exteriority' (Foucault and Blanchot 1990, p. 11).33 Language thought in this way, Foucault points out, is no longer discourse and the communication of meaning; it gives expression to what we earlier referred to as the absence of an œuvre. This of course has important implications for the speaking subject who can now no longer be said to coincide with itself, but which fragments, disperses, scatters, disappears in the naked space of language. The speaking subject can no longer be viewed as a responsible agent in the traditional sense, as it is more accurately a non-existence through which language pours forth (Foucault and Blanchot 1990, p. 11). This brings us to the point where we can say, Foucault contends, that modern literature is not, as is often believed, characterised by a doubling-back, a self-designation, a self-reference or interiorization. The event from which 'literature' in the strict sense arises, rather involves a passage to the 'outside', 34 language getting as far away from itself as possible (Foucault and Blanchot 1990, p. 12). Literature hence shows itself not as a folding back, but as a gap, a dispersion of signs. Literature consequently concerns itself not with the positivity of language, but with the void which language takes as its space. Whereas in the past it was a matter of thinking through the truth, it is now a matter of thinking through fiction, Foucault points out (Foucault and Blanchot 1990, pp. 12-13). Foucault at this point contrasts

\footnotetext{
${ }^{32}$ We can also say that like any other statement, this statement (I speak) 'does not require the presence or assistance of any party, male or female. The statement survives them a priori, lives on after them' (Derrida 2004, p. 64).

${ }^{33}$ The phrase "Blanchot's "I speak" must of course be qualified because Blanchot makes us acutely aware of the distinction between the author, the narrator and the character(s) in fiction. Derrida speaks in this respect (in relation to Blanchot's texts) of 'a certain neutrality of the "narrative voice," a voice without person, without the narrative voice from which the "I" posits and identifies itself" (Blanchot and Derrida 1998, p. 27). In this division, another division is in turn announced: of the author, the narrator and the character(s) as themselves divided in themselves by death (Blanchot and Derrida 1998, pp. 53-54). Blanchot furthermore distinguishes between the narrative voice and the narratorial voice, the latter being the voice of the subject identical with itself (Derrida 2004, p. 86). The narrator, as Derrida (2004, pp. 99, 115) furthermore points out, is identical with death and at the same time condemned to live on in Blanchot's texts.

34 The quotation marks are Foucault's. Foucault thereby acknowledges the problematic nature of the metaphysical distinction between an inside and an outside. This also appears inter alia from his discussion of 'the companion' in Blanchot's texts (Foucault and Blanchot 1990, pp. 47-52). Foucault's description of the 'outside' as 'there, open, without intimacy, without protection or retention' and as never yielding its essence, furthermore clearly ties in with the notion of attraction, to be discussed below, and with death (Foucault and Blanchot 1990, pp. 27-28, 48 and 57).
} 
Blanchot's 'I speak' with Descartes's 'I think'. Whereas the latter was supposed to lead to the indubitable certainty of the I and its existence, Blanchot's 'I speak' distances, disperses and effaces that existence. In light of our earlier enquiry, we can perhaps say that Blanchot, like Descartes before him, points to the evil genius as the condition of possibility of speech. In Blanchot however there is no attempt at a reassurance of the self after this 'confrontation'. Can law follow Blanchot in the adoption of a narrative voice? Foucault's challenge is for law to do so.

The law itself

In the paragraph 'Where Is the Law, And What Does It Do?' Foucault considers the manifestation and withdrawal of the law with reference to The Most High and Aminadab (Foucault and Blanchot 1990, pp. 33-40). From the discussion above and the context it can already be seen that the law which is at stake here is not simply (some dimension or mode of becoming of) modern law, but the law of language, a deathly desire in other words, total madness, the law itself. Foucault starts this paragraph by mentioning the relation between being negligent and the attraction of the law, which will be contrasted with the attempt to provoke the law, leading in turn to the simple opposition between law and punishment. Before we continue with a discussion of this distinction, a brief analysis of the notions of attraction and negligence is required. Foucault earlier in the text draws a close parallel between what Blanchot refers to as attraction, Sade as desire, Nietzsche as force, Artaud as the materiality of thought, and Bataille as transgression. According to Foucault, all of these refer to 'the pure, most naked, experience of the outside' (Foucault and Blanchot 1990, p. 27). Attraction, as Foucault points out, implicitly referring to Aminadab,

has nothing to offer but the infinite void that opens beneath the feet of the person it attracts, the indifference that greets him as if he were not there, a silence too insistent to be resisted and too ambiguous to be deciphered and definitively interpreted - nothing to offer but a woman's gesture in a window, a door left ajar, the smile of a guard before a forbidden threshold, a gaze condemned to death (Foucault and Blanchot 1990, p. 28).

Foucault furthermore points out that 'negligence' is the necessary correlate of attraction in Blanchot's texts. He describes negligence as a total disregard for what one is doing and detects such a disregard in Thomas's action in Aminadab when he enters the boarding house, simply because he refrains from entering the house across the street as well as in the fact that Thomas's past, family and other life is of no relevance here; it is non-existent (Foucault and Blanchot 1990, p. 28). The link which Foucault sees between attraction/negligence and death/madness appears very clearly from the paragraph on Eurydice and the Sirens where Foucault explores Blanchot's The Gaze of Orpheus and The Song of the Sirens (Foucault and Blanchot 1990, pp. 41-45). The enchantment of the Sirens, Foucault points out, lies in the fatal promise of their singing. The Sirens are only their song, a pure appeal. Their melody simply 
promises a future song, to tell one all about oneself. This is both the truth and a lie: a lie, because listening to them inevitably leads to death; but also the truth, because death makes the song possible as well as the endless recounting of the heroes' adventure (that is, 'I speak'). Odysseus/Ulysses only survives to tell the tale because of his being tied to the mast and his crew's ears having been plugged. Foucault sees Eurydice as a close relative of the Sirens. She is as enchanting as the Sirens, her enchantment lying in the promise of a face as compared to theirs which lies in song. Unlike Odysseus, Orpheus was not however chained to a mast, neither were his ears blocked. Orpheus could therefore be seized completely by the forbidden desire. This makes for an important difference between the triumphant narrative told by Odysseus and the lament and absolute loss of Orpheus. As Foucault points out, behind Odysseus's narrative one can hear the inaudible lament of not having surrendered to the Sirens (Foucault and Blanchot 1990, p. 43). Behind Orpheus's laments one can on the other hand detect the glory of having seen for a fleeting moment the unattainable face (the open gaze of death), just before it concealed itself again in darkness. 35

At this point we can return again to Foucault's reflections on the law itself, from which we will see how the latter ties in with the notions of attraction and negligence. The law, Foucault notes, is not self-evident and in the heart, as then it would simply be something in consciousness. It is also not present in a text, possible to decipher in a book, or possible to consult in a register. If it were so present (as, one could add, is the case with law in its manifestation, that is, positive law) it would have been possible to follow or disobey it. The law would then however have no power, force or prestige to demand respect. Foucault adds that the law haunts cities, institutions, conduct and gestures in a sovereign way; it always applies its might, irrespective of what one does, of the chaos that prevails. Provoking or violating the law is not sufficient to interrupt it as this simply leads to punishment. ${ }^{6}$ One cannot simply detach oneself from the law and observe its exercise from a distance. If you think you can do so and that the law applies only to other people, this is the moment that you are closest to the law, that you make it circulate. In this perpetual manifestation of the law (for example through public decrees) what the law says or wants is however never illuminated. Foucault explains this statement as follows:

[T] he law is not the principle or inner rule of conduct. It is the outside that envelops conduct thereby removing it from all interiority; it is the darkness beyond its borders; it is the void that surrounds it, converting, unknown to anyone, its singularity into the gray monotony of the universal and opening around it a space of uneasiness, of dissatisfaction, of multiplied zeal.

\footnotetext{
${ }^{35}$ Derrida, in his analysis of Blanchot's 'The Instant of my Death', gives expression to what is at stake here by referring to death as 'an immense orgiastic jouissance' (Blanchot and Derrida 1998, p. 68).

${ }^{36}$ The implicit reference here is to The Most High which sketches in Hegelian terms the all-embracing concern of the law. This eg finds expression in the following remark of Bouxx (the revolutionary) in The Most High (Blanchot 1996, p. 42): 'The State has pressed into service everything you can say and everything you can do. There isn't a single thought that doesn't bear its mark. All governments are like this.' The Most High of course also seeks to go beyond Hegel in this respect.
} 
And of transgression. How could one know the law and truly experience it, how could one force it to come into view, to exercise its powers clearly, to speak, without provoking it, without pursuing it into its recesses, without resolutely going ever farther into the outside into what is always receding? (Foucault and Blanchot 1990, p. 34) 37

These enigmatic passages can be analysed endlessly. A few words on them will have to suffice here. From the preceding discussion of some of the concepts that appear in these passages such as the law, the outside, the void, negligence (which Foucault connects with zeal), and the phrase 'to speak', it has already appeared that these concepts resonate with Foucault's reflections on madness. $3^{8}$ One should therefore be careful to avoid a reading of these passages which understands the law at stake here simply in terms of subjectivity, consciousness and interiority. Such a reading would shift the focus from the law itself to its manifestation, from the impossible to the possible, from madness to reason. It would risk installing law comfortably within metaphysics. 39 An enquiry into the relation between transgression and provocation, referred to in the above passages, further shows what is at stake here, as well as its close relation to our earlier discussion of madness and desire. Foucault points out in this respect that Blanchot does not merely concern himself with the provocation of law, but also with its transgression (Foucault and Blanchot 1990, p. 35). Whereas provocation simply confirms the law in its effectiveness, transgression is closely aligned to attraction/negligence: it seeks 'to attract the law to itself; it always surrenders to the attraction of the essential withdrawal of the law; it obstinately advances into the opening of an invisibility over which it will never triumph' (Foucault and Blanchot 1990, p. 35).40 Transgression insanely, but simply, attempts to venerate the law; to reinforce the law in its weakness - the lightness of the night which is law's 'invincible, impalpable substance' (Foucault and Blanchot 1990, p. 35). The law, Foucault furthermore notes, 'is the shadow towards which every gesture necessarily advances; it is itself the shadow of the advancing gesture' (Foucault and Blanchot 1990, p. 35). In somewhat simpler terms: the transgression of law in its manifestation and in its collusion with reason, can, as in the case of literature, be undertaken only by approaching the law itself by way of an impossible

\footnotetext{
${ }^{37}$ See also Golder and Fitzpatrick (2009, pp. 78ff) where these passages are cited and discussed, in the process of the formulation of the main thesis of the book.

${ }^{38}$ See similarly, Derrida's remark in 'The Law of Genre' (Derrida 1992, p. 251): 'The law is mad. The law is mad, is madness; but madness is not the predicate of law. There is no madness without the law; madness cannot be conceived before its relation to law. This is the law, the law is madness.' Law's division within itself also appears eg from Derrida (1987b, p. 15) where he speaks of ' $[\mathrm{t}]$ he law itself, the law above other laws'.

${ }^{39}$ In Golder and Fitzpatrick (2009, pp. 78-82), the 'other law' at stake in Foucault is viewed as one dimension of the law (in opposition to law's determinate side) and as constantly on the move and responsive to new and/or fresh possibilities, instantiations and determinations. Law's responsive dimension is also described as law necessarily assuming a 'labile existence', as 'law's constituently holding itself open to new ways of being' (at p. 82) and as holding 'itself ever open to unthought possibilities' (at p. 85). The authors in my view succeed to a greater extent in providing a reading of Foucault which exceeds metaphysics when they refer simply to something 'radically uncontainable in Foucault's law' (at p. 2).

${ }^{40}$ See also Derrida in Blanchot and Derrida (1998, p. 87) on Blanchot's notion of transgression: “"Transgression transgresses out of passion, patience, passivity." Transgression is thus not a decision, certainly not a decision as activity of the ego or voluntary calculation of the subject.'
} 
orgiastic desire for death, by way of total madness, a mad and impossible hospitality, infinite and unconditional, without limitation, control or reciprocity.

\section{Law's absolute demand 41}

The 'projects' of Foucault and Derrida have often been thought of as in opposition to each other. When one however carefully scrutinises their relation to the texts of Descartes and Blanchot, it appears that they share a certain space. This shared space is not however situated 'within', but at a certain 'remove' from metaphysics. A reading of Foucault and Derrida is in other words called for which allows us to see them as at a certain point exceeding metaphysics, a complete escape nevertheless remaining impossible. Such a reading allows us to view madness, also in Foucault's texts, in a transgressive 'sense' and at the same time to appreciate the point or site from which he launches his radical and necessary critique of modernity. This 'site' speaks of a madness beyond reason, a deathly desire, an anachronous time, a past which has never been present and which always remains to come. Madness in this 'sense' can also be referred to as the law itself, justice or absolute hospitality. This mad hospitality, the law itself, enables us to see that behind the contingent and determined exclusion of 'marginalised others' which Foucault exposes, a more radical exclusion always takes place which makes these exclusions possible in the first place. These exclusions can never be fully justified, which opens up the law to transformation, not simply towards the possible, but the impossible; to law itself in its inevitable withdrawal. In the words of Foucault:

The law averts its face and returns to the shadows the instant one looks at it; when one tries to hear its words, what one catches is a song that is no more than the fatal promise of a future song (Foucault and Blanchot 1990, p. 41).

Acknowledgements Funding for this research was provided by the South African National Research Foundation. A shortened version of the article was presented at the Critical Legal Conference, 11-13 September, 2009, University of Leicester. I would like to express my gratitude to the participants for their thoughtful comments.

\footnotetext{
${ }^{41}$ The heading is derived from Blanchot (1992, p. 24).
} 


\section{References}

Blanchot, Maurice, 1992. The step not beyond. New York: State University of New York Press.

Blanchot, Maurice. 1996. The Most High. Lincoln and London: University of Nebraska Press.

Blanchot, Maurice. 1999. The Station Hill Blanchot Reader: Fiction \& literary essays. New York: Station Hill/Barrytown Ltd.

Blanchot, Maurice. 2002. Aminadab. Lincoln and London: University of Nebraska Press.

Blanchot, Maurice, and Jacques Derrida. 1998. The instant of my death/Demeure: fiction and testimony. Stanford: Stanford University Press.

Boyne, Roy. 1990. Foucault and Derrida: the other side of reason. New York and London: Routledge.

Derrida, Jacques. 1974. Of grammatology. Baltimore and London: The John Hopkins University Press.

Derrida, Jacques. 1978. Writing and difference. New York and London: Routledge.

Derrida, Jacques. 1982. Margins of philosophy. Chicago: The University of Chicago Press.

Derrida, Jacques. 1986. Glas. Lincoln and London: University of Nebraska Press.

Derrida, Jacques. 1987a. The post card: From Socrates to Freud and beyond. Chicago and London: The University of Chicago Press.

Derrida, Jacques. 1987b. The laws of reflection: Nelson Mandela, in admiration. In For Nelson Mandela, ed. Jacques Derrida and Mustapha Tlili, 13-42. New York: Seaver Books.

Derrida, Jacques. 1988. Limited Inc. Evanston: Northwestern University Press.

Derrida, Jacques. 1992. Acts of literature. New York and London: Routledge.

Derrida, Jacques. 1998. Resistances of psychoanalysis. Stanford: Stanford University Press.

Derrida, Jacques. 1999. Adieu to Emmanuel Levinas. Stanford: Stanford University Press.

Derrida, Jacques. 2002. Acts of religion. New York and London: Routledge.

Derrida, Jacques. 2004. Living On. In Bloom et al Deconstruction and criticism, 62142. London and New York: Continuum.

Derrida, Jacques. 2008. Psyche: Inventions of the other, vol II. Stanford: Stanford University Press.

Derrida, Jacques, and Anne Dufourmantelle. 2000. Of hospitality. Stanford: Stanford University Press.

Derrida, Jacques, and Elizabeth Roudinesco. 2004. For what tomorrow...A dialogue. Stanford: Stanford University Press.

Derrida, Jacques, and Paule Thévenin. 1998. The secret art of Antonin Artaud. Cambridge, Massachusetts and London: The MIT Press.

Descartes, René. 1968. Discourse on method and the meditations. London: Penguin Books. 
Felman, Shoshana. 1975. Madness and philosophy or literature's reason. Yale French Studies 52: 206-228.

Flynn, Bernard. 1989. Derrida and Foucault: Madness and writing. In Derrida and deconstruction, ed. Hugh J. Silverman, 201-218. New York and London: Routledge.

Foucault, Michel. 1988. Politics philosophy culture: Interviews and other writings 1977-1984. New York and London: Routledge.

Foucault, Michel. 2006. History of madness. London and New York: Routledge.

Foucault, Michel, and Maurice Blanchot. 1990. Foucault/Blanchot. New York: Zone Books.

Freud, Sigmund. 2001. The standard edition of the complete psychological works of Sigmund Freud volume XVIII (1920-1922). London: Vintage.

Freundlieb, Dieter. 1995. Foucault and the study of literature. Poetics Today 16(2): 301-344.

Golder, Ben and Peter Fitzpatrick. 2009. Foucault's law. New York and London: Routledge.

Hartman, Geoffrey H. 1955. The fulness and nothingness of literature. Yale French Studies 16: 63-78.

Johnston, John. 1990. Discourse as event: Foucault, writing, and literature. MLN 105(4): 800-818.

McNay, Lois. 1994. Foucault: A critical introduction. New York: Continuum.

Naas, Michael. 2003. Taking on the tradition: Jacques Derrida and the legacies of deconstruction. Stanford: Stanford University Press.

Nietzsche, Friedrich. 2003. Thus spoke Zarathustra. London: Penguin Books.

Plato. 1997. Complete works, ed. John M. Cooper.

Rajchman, John. 1983. Foucault, or the ends of modernism. October 24: 37-62.

Saghafi, Kas. 1996. The "passion for the outside": Foucault, Blanchot, and exteriority. International Studies in Philosophy 28:79-92.

Said, Edward. 1978. The problem of textuality: two exemplary positions. Critical Enquiry 4: 673-714.

Santini, Sylvano, and Roxanne Lapidus. 2002. Michel Foucault: Literature and the arts: A report from the colloquium at Cerisy-la-Salle, June 23-30, 2001. SubStance 31(1) $77-84$.

\section{JACQUES DE VILLE}

Faculty of Law

University of the Western Cape

Private Bag X17

Bellville, Cape Town,

7535,

South Africa

E-mail: jdeville@uwc.ac.za 